\title{
PERLINDUNGAN HUKUM ATAS PRAKTIK PUNGUTAN LIAR DI KANTOR PELAYANAN PUBLIK
}

\author{
Shintamy Nesyicha Syahril ${ }^{1}$, Tundjung Herning Sitabuana ${ }^{2}$ \\ ${ }^{1}$ Program Studi Magister Hukum, Universitas Tarumanagara Jakarta \\ Email: cintasyahril99@gmail.com \\ ${ }^{2}$ Dosen Magister Hukum, Universitas Tarumanagara Jakarta \\ Email: tundjung@fh.untar.ac.id
}

\begin{abstract}
Illegal levies are still a tradition in Indonesia since the Dutch colonial era. Extortion usually often occurs in public service offices. This certainly violates the rights of citizens to obtain legal protection. Indonesia as a country based on law, of course, has guaranteed legal protection in the constitution. Extortion is a criminal act, extortion often occurs because of the low level of legal awareness of public service office employees. With the practice of extortion, of course, it is contrary to what is expected in the state goals as stated in the Preamble to the 1945 Constitution of the Republic of Indonesia. Illegal levies are an act of government employees that hinders the welfare of the community and causes public distrust of the state. Criminal policies related to illegal levies are contained in Article 348 paragraph (1) and Article 432 of the Criminal Code. Illegal levies can be categorized as a criminal act of extortion. Illegal levies often occur because of the lack of supervision from government agencies authorized to oversee the implementation of public services. To ensure the implementation of public services that are free from illegal fees, more detailed regulations and tighter supervision from the government are needed. The higher the level of legal culture of public service employees, it will guarantee the rights of legal protection of citizens so that a prosperous country can be realized. This research uses normative research methods.
\end{abstract}

Keywords: Illegal Levies, Legal Protection, Public Service Office, Legal Culture, Supervision

\begin{abstract}
ABSTRAK
Pungutan liar masih menjadi tradisi di Indonesia sejak jaman kolonial Belanda. Pungutan liar biasanya sering terjadi di kantor pelayanan publik. Hal ini tentu melanggar hak warga negara untuk mendapatkan perlindungan hukum. Indonesia sebagai negara yang berlandaskan hukum, tentu saja telah menjamin perlindungan hukum di dalam konstitusi. Pungli merupakan merupakan suatu tindak pidana, pungli sering terjadi karena rendahnya tingkat kesadaran hukum pegawai kantor pelayanan publik. Dengan terjadinya praktik pungli tentu saja bertentangan dengan apa yang diharapkan dalam tujuan negara yang tercantum dalam Pembukaan Undang-Undang Dasar Republik Indonesia Tahun 1945. Pungutan liar merupakan suatu perbuatan pegawai pemerintah yang menghambat kesejahteraan masyarakat serta menyebabkan timbulnya ketidakpercayaan masyarakat terhadap negara. Kebijakan pidana terkait pungutan liar terdapat di dalam Pasal 348 ayat (1) dan Pasal 432 Kitab Undang-Undang Hukum Pidana. Pungutan liar dapat dikategorikan sebagai tindak pidana pemerasan. Pungutan liar kerap terjadi karena kurangnya pengawasan dari lembaga pemerintah yang berwenang mengawasi penyelenggaraan pelayanan publik. Untuk menjamin terlaksananya pelayanan publik yang bebas dari pungutan liar, maka dibutuhkan pengaturan yang lebih rinci serta pengawasan yang lebih ketat dari pemerintah. Semakin tinggi tingkat budaya hukum pegawai pelayanan publik, maka akan menjamin hak perlindungan hukum warga negara sehingga negara yang sejahtera dapat terwujud. Penelitian ini menggunakan metode penelitian normatif.
\end{abstract}

Kata Kunci: Pungutan Liar, Perlindungan Hukum, Kantor Pelayanan Publik, Budaya Hukum, Pengawasan

\section{PENDAHULUAN}

Latar Belakang

Indonesia sebagai negara hukum merupakan konsep negara yang berjalan berlandakan hukum, bukan lagi kekuasaan. Pemerintahan harus dijalankan berdasarkan peraturan-peraturan. Namun nyatanya pada praktik pemerintahan dalam bentuk pelayanan publik sering ditemukan pungutan liar. Pungutan liar (pungli) adalah perbuatan yang menagih pembayaran sejumlah uang yang dilakukan pegawai birokrasi tanpa adanya peraturan yang berkenaan dengan penagihan tersebut. Maka tentu saja mengganggu rasa keadilan masyarakat yang merasa tidak diperlakukan sebagaimana mestinya oleh pegawai birokrasi. 
Pungutan liar yang dilakukan oleh pegawai birokrasi merupakan salah satu bentuk kejahatan korupsi karena menggunakan kekuasaannya untuk menagih sejumlah uang kepada masyarakat tanpa adanya peraturan yang berlaku demi menguntungkan diri sendiri. Namun pada dasarnya masyarakat tidak dapat menghindar dari pungutan liar tersebut dikarenakan apapun yang dibutuhkan oleh masyarakat sebagai warga negara di Indonesia tentu saja selalu berkaitan dengan praktik birokrasi. Di Indonesia, praktik pungli ini sering dilakukan oleh pegawai birokrasi kelas bawah yang biasanaya bergaji rendah. Hal tersebut dilakukan karna sering kali tidak terdapat pengawasan dalam berlangsungnya pelayanan publik, sehingga kelonggaran tersebut dijadikan celah untuk menggunakan kekuasaannya dalam memeras masyarakat.

Fenomena tersebut sudah menjadi tradisi dalam penyelenggaran pelayanan publik di Indonesia. Bahkan budaya hukum yang tidak baik tersebut telah terjadi sejak zaman penjajahan Belanda, yang tujuannya tentu saja tidak untuk mementingkan kesejahteraan rakyat Indonesia, melainkan memanfaatkan kekayaan Indonesia untuk kepentingan negara penjajah. Maka hal ini tentu saja menimbulkan persoalan mengenai keadilan serta perlindungan hukum masyarakat sebagai warga negara. Tradisi ini tentu saja tidak sejalan dengan tujuan utama negara negara Indonesia yang diharapkan oleh konstitusi sehingga keadaan tersebut mengakibatkan "public distrust" terhadap pelayanan publik di Indonesia.

Di dalam konstitusi telah ditentukan bahwa pemerintah merupakan wakil dari negara yang menjalankan fungsi perlindungan atas hak asasi manusia. Perlindungan hukum pada kantor pelayanan publik ini harus ditegakkan agar dapat menjamin hak-hak warga negara dalam mengurus hal-hal administrasi yang berkaitan dengan negara. Maka dari itu, pungutan liar tentu saja menjadi masalah yang serius yang dihadapi Indonesia. Hal ini menunjukkan bahwa rendahnya budaya hukum para pegawai birokrasi sehingga melanggar hak perlindungan hukum warga negara.

\section{Rumusan Masalah}

Berdasarkan latar belakang yang telah paparkan di atas, maka terdapat permasalahan yang dapat diangkat dalam penelitian ini :

a) Bagaimana perlindungan hukum atas praktik pungutan liar di kantor pelayanan publik?

b) Bagaimana peran pemerintah dalam menjamin perlindungan hukum warga negara atas praktik pungutan liar di kantor pelayanan publik?

\section{METODE PENELITIAN}

Metode penulisan yang digunakan merupakan penelitian hukum normatif. Penelitian hukum normatif merupakan penelitian yang menggunakan bahan baku utama, menelah hal yang bersifat teoritis yang berkaitan dengan asas-asas hukum, teori hukum, pandangan para ahli hukum, peraturan dan sistem hukum dengan menggunakan data sekunder, diantaranya: asas, kaidah, norma dan aturan hukum dapat ditemukan dalam peraturan perundang-undangan dan peraturan lainnya, dengan mempelajari sejumlah buku maupun penulisan-penulisan yang berkaitan dengan masalah yang diangkat dalam penelitian. Penelitian ini bersifat deskriptif analitis serta menggunakan teknik pengumpulan data yang bersifat normatif. Penelitian ini menggunakan data sekunder serta teknik analisis data kualitatif.

\section{HASIL DAN PEMBAHASAN}

\section{Perlindungan hukum atas praktik pungutan liar di kantor pelayanan publik}

Konstitusi telah menjamin bahwa setiap warga negara Indonesia mendapatkan perlindungan hukum dari negara. Namun pada kenyataannya keberadaan pungli tidak dapat dihindari. Pungutan liar (pungli) adalah perbuatan yang menagih pembayaran sejumlah uang yang dilakukan pegawai birokrasi tanpa adanya peraturan yang berkenaan dengan penagihan tersebut 
atau tidak sesuai dengan jumlah yang telah ditentukan di dalam peraturan tersebut. Pungli pada dasarnya merupakan suatu kejahatan yang dilakukan oleh pegawai birokrasi di kantor pelayanan publik untuk memeras rakyat.

Berdasarkan Pasal 1 ayat (1) Undang-Undang Nomor 25 Tahun 2009 tentang Pelayanan Publik, dinyatakan bahwa:

"pelayanan publik adalah kegiatan atau rangkaian kegiatan dalam rangka pemenuhan kebutuhan pelayanan sesuai dengan peraturan perundangundangan bagi setiap warga negara dan penduduk atas barang, jasa, dan/atau pelayanan administratif yang disediakan oleh penyelenggara pelayanan publik."

Mengenai hal tersebut tentu saja melanggar salah satu hak warga negara dalam mendapatkan perlindungan hukum di kantor pelayanan publik. Menurut Satjipto Raharjo, perlindungan hukum merupakan usaha untuk menyusun berbagai macam kebutuhan dalam masyarakat agar tidak bertubrukan dengan kepentingan lain dan dapat menikmati semua hak yang telah dijamin oleh hukum. Perlindungan hukum merupakan sebuah pengakuan serta jaminan yang diberikan oleh hukum yang berkaitan dengan hak asasi manusia. Dengan kata lain, perlindungan hukum merupakan bentuk realisasi tujuan hukum untuk mendapatkan suatu keadilan, kepastian dan kemanfaatan.

Indonesia sebagai negara hukum tentu saja mengakui adanya perlindungan HAM. Hal ini sejalan dengan pendapat Friedrich Julius Stahl terkait ciri negara hukum. Stahl berpendapat bahwa negara hukum menjamin adanya perlindungan HAM, terdapat pemisahan atau pembagian kekuasaan, kemudian pemerintahan berdasarkan peraturan-peraturan dan serta peradilan administrasi yang bebas dalam perselisihan.

Di Indonesia, praktik pungli ini sering kali dilakukan oleh pegawai birokrasi kelas bawah yang mana hal ini dengan mudah dilakukan karena kurangnya pengawasan. Seperti yang telah dijabarkan diatas bahwa perlindungan hukum merupakan salah satu hal yang diamanatkan oleh konstitusi. Konstitusi adalah hukum tertinggi di Indonesia yang menjadi merupakan suatu piagam yang terdapat cita-cita bangsa serta menjadi dasar berjalannya suatu organisasi kenegaraan suatu bangsa. Pada Pasal 27 ayat (1) UUD NRI 1945, dijelaskan bahwa warga negara berhak mendapatkan perlindungan hukum.

Menurut Lawrence M. Friedman dalam teorinya "sistem hukum", untuk menentukan berhasil atau tidaknya suatu penegakkan hukum bergantung pada substansi hukum, struktur hukum, serta budaya hukum. Jika berdasarkan teori ini, maka substansi hukum sebagai bentuk produk hukum yang berkaitan dengan pungli telah diatur dalam Kitab Undang-Undang Hukum Pidana (KUHP), yang mana jika untuk perseorangan maka terdapat pada Pasal 368 ayat (1) KUHP yang menyatakan :

"Barang siapa dengan maksud untuk menguntungkan diri sendiri atau orang lain secara melawan hukum, memaksa seorang dengan kekerasan atau ancaman kekerasan untuk memberikan barang sesuatu, yang seluruhnya atau sebagian adalah kepunyaan orang itu atau orang lain, atau supaya membuat utang maupun menghapuskan piutang, diancam karena pemerasan, dengan pidana penjara paling lama sembilan tahun."

Sedangkan untuk pegawai negeri terdapat pada Pasal 423 KUHP, yang menyatakan :

"Pegawai negeri yang dengan maksud menguntungkan diri sendiri atau orang lain, secara melawan hukum, dengan menyalahgunakan kekuasaannya, memaksa orang lain, untuk menyerahkan sesuatu, melakukan suatu pembayaran, melakukan pemotongan terhadap 
suatu pembayaran, melakukan suatu pekerjaan untuk pribadi sendiri, dipidana dengan pidana penjara selama-lamanya 6 tahun".

Kemudian jika terkait dengan struktur hukum maka hal itu merujuk pada kelembagaan yang menjalankan hukum. Dan yang terakhir mengenai pungli, maka hal tersebut sangat berkaitan erat dengan budaya hukum. Alasan praktik pungli ini masih terjadi karena budaya hukum para pegawai birokrasi di kantor pelayanan publik Indonesia sangat rendah. Budaya hukum berkaitan erat dengan kesadaran hukum masyarakat. Kesadaran hukum berkaitan dengan kondisi pemikiran sosial serta kekuatan sosial yang menetapkan bagaimana hukum itu dipergunakan, dihindari, ataupun disalahgunakan.

Dalam praktik pungli ini, dapat kita pahami bahwa para pegawai birokrasi telah menyalahgunakan kekuasaannya dalam meminta sejumlah uang kepada masyarakat tanpa adanya peraturan yang berlaku terkait pungutan tersebut. Pegawai birokrasi Indonesia yang harusnya melayani, malah terkesan dilayani. Semakin tinggi tingkat kesadaran masyarakat dalam menjalankan suatu hukum, maka semakin besar tingkat keberhasilan hukum tersebut. Jika pegawai birokrasi yang seharusnya bertugas melayani masyarakat memiliki tingkat kesadaran yang tinggi, tentu saja perlindungan hukum kepada warga negara seperti yang diamanatkan konstitusi lebih mudah tercapai.

Selanjutnya, apabila perlindungan hukum itu tercapai, tentu saja tujuan negara Indonesia yang telah dirumuskan dalam Alinea 4 Pembukaan Undang-Undang Dasar 1945, yakni untuk memajukan kesejahteraan bangsa juga tercapai. Indonesia menganut paham negara kesejahteraan bukan negara penjaga malam, yang mana Moh. Hatta memilih menyebutnya dengan "negara pengurus". Hal tersebut dipertegas pada Pasal 33 Undang-Undang Dasar 1945 yang memiliki makna bahwa pembangunan yang baik dikerjakan oleh pemerintah dilakukan sebesar-besarnya untuk kemakmuran rakyat. Jika perlindungan dan penegakkan hukum berjalan dengan baik, maka prinsip negara kesejahteraan akan terwujud.

\section{Peran pemerintah dalam menjamin perlindungan hukum warga negara atas praktik Pungutan liar di kantor pelayanan publik.}

Seperti yang telah kita diketahui, bahwa Indonesia merupakan negara yang berlandaskan hukum, maka hukum yang merupakan produk dari penyelenggara negara perlu diawasi. Suatu pemerintahan yang baik mengutamakan perlindungan hukum atas warga negaranya. Namun untuk menjaminnya suatu pemerintahan yang baik, maka diperlukan pengawasan. Pengawasan perlu dilakukan untuk menentukan apakah suatu kegiatan telah dilaksanakan berjalan sesuai dengan standar yang telah ditentukan sebelumnya.

Dalam penyelenggaraan pemerintahan khususnya dibidang pelayanan publik, pemerintah telah membentuk Peraturan Presiden Nomor 87 Tahun 2016 Tentag Satuan Tugas Sapu Bersih Pungutan Liar. Peraturan ini lahir karena praktik pungutan liar telah merusak kehidupan bermasyarakat dan berbangsa, sehingga dibentuklah Satgas Saber Pungli yang bertugas mengawasi jalannya pelayanan publik yang dapat memberantas pungutan liar. Adanya peraturan ini menegaskan bahwa pungli merupakam tindak pidana yang harus diberantas. Kemudian, masyarakat sebagai "korban kejahatan" atas praktik pungli ini dapat mengirim sms ke satgas pungli untuk membantu jalannya peraturan ini dengan baik.

Namun perpres ini dinilai tidak memadai karena pembentukannya juga tidak berdasarkan undang-undang yang jelas. Kemudian, tidak tentukan batasan mana yang disebut tindakan pungutan liar atau tidak. Hal juga ini menimbulkan konflik tumpang tindih dengan kewenangan yang dimiliki Ombudsman merupakan lembaga negara yang bertugas mengawasi jalannya pelayanan publik. 
Meski masyarakat diminta untuk turun tangan dalam memberantas pungli demi menjaga haknya sebagai warga negara, namun pada nyatanya apabila masyarakat tidak membayar sejumlah uang yang ditagih oleh pegawai pelayanan publik (sebagai bentuk uang pelicin), maka urusannya tidak akan diselesaikan dengan cepat. Oleh karena itu, mau tidak mau masyarakat harus membayar pungutan liar tersebut. Lantas apabila pengawasan ini lebih dominan dilakukan dengan cara pengaduan, itu tidak akan efektif. Pemerintah dalam hal ini telah mengutus Satber Pungli harus mengawasi penyelenggaraan pelayanan publik secara intens dan berkala agar pungli dapat dicegah secara efektif sehingga dapat meningkatkan kepercayaan publik kepada negara.

\section{KESIMPULAN DAN SARAN}

\section{Kesimpulan}

Pungutan liar adalah perbuatan yang menagih pembayaran sejumlah uang yang dilakukan pegawai birokrasi tanpa adanya peraturan yang berkenaan dengan penagihan tersebut maupun penagihan yang tidak sesuai dengan jumlah yang telah ditentukan. Praktik pungli ini terjadi karena kurangnya kesadaran hukum para pegawai di kantor pelayanan publik, serta kurangnya pengawasan dalam penyelenggaraannya sehingga memberikan celah untuk memeras masyarakat. Hal ini tentu bertentangan dengan hak warga negara untuk mendapatkan perlindungan hukum seperti yang telah dijamin oleh konstitusi. Maka apabila tidak terjaminnya hak perlindungan hukum bagi setiap warga negara, akan mempengaruhi kesejahteraan masyarakat yang mana merupakan tujuan negara Indonesia yang tercantum dalam konstitusi. Pemerintah telah membentuk Satuan Tugas Sapu Bersih Pungutan Liar yang bertugas memberantas praktik pungutan liar, yang terdapat pelayanan pengaduan yang dapat dilakukan oleh masyarakat, meskipun tampaknya peraturan tersebut kurang berjalan efektif karena tidak ditentukannya batasan mana perbuatan yang disebut pungutan liar atau tidak serta timpang tindih dengan kewenangan yang dimiliki Ombudsman.

\section{Saran}

Untuk memberantas pungli agar tercapai perlindungan hukum serta terwujudnya kesejahteraan negara, maka diperlukan sosialisasi yang berkaitan dengan kesadaran hukum kepada para pegawai pelayanan publik. Kemudian, diperlukannya pengawasan yang lebih intens oleh Saber Pungli serta sosialisasi kepada masyarakat mengenai nomor pengaduan apabila menemukan praktik pungli. Terakhir, dibutuhkannya pengaturan yang lebih jelas terkait pungli. Harus ditentukan batasan mana yang disebut dengan praktik pungutan liar atau tidak, serta hukuman yang jelas agar dapat menimbulkan efek jera. Seperti yang diketahui bahwa kebijakan pidana praktik pungli berada di dalam KUHP, alangkah lebih baik jika disebutkan dalam peraturan yang jelas terkait pungli.

\section{Ucapan Terima Kasih (Acknowledgement)}

Penulis mengucapkan terima kasih yang sebesar-besarnya kepada civitas akademika Program Studi Magister Hukum Universitas Tarumanagara khususnya kepada Dr. Tundjung Herning Sitabuana, S.H., C.N., M.Hum. selaku dosen Magister Hukum yang selalu memberikan arahan dan motivasi, sehingga penulis dapat menyelesaikan tulisan ini dengan baik.

\section{REFERENSI}

Raharjo, Satjipto. (2000). Ilmu Hukum. PT. Citra Aditya Bakti, Bandung.

Dwiyanto, Agus. (2005). Mewujudkan Good Governance Melalui Pelayanan Publik. Pustaka Pelajar, Yogjakarta.

Soekanto, Soerjono. (2006). Penelitian Hukum Normatif. PT Raja Grafindo Peresada, Jakarta. 
Yamin, M. (1959). Naskah Persiapan UUD 1945: Risalah Sidang BPUPKI/PPKI. Sekretariat Negara RI, Jakarta.

Sirajun. (2012). Hukum Pelayanan Publik. Setara Press, Malang.

Ramadhani, Wahyu. (2017). Penegakan Hukum Dalam Menanggulangi Pungutan Liar Terhadap Pelayanan Publik. Jurnal Hukum Samudra Keadilan, Volume 12 (Nomor 2), 276.

Nuriyanto. (2015). Membangun Budaya Hukum Pelayanan Publik untuk Mewujudkan Kesejahteraan Rakyat. Integritas, Volume 1 (Nomor 1), 19.

Solahuddin, Moh Toha. (2016). Pungutan Liar Dalam Perspektif Tindak Pidana Korupsi. Paraikatte, Edisi Triwulan II Vol 26, 4.

Muabezi, Zahermann Armandz. (2017). Negara Berdasarkan Hukum (Rechtsstaats) Bukan Kekuasaan (Machtsstaat). Jurnal Hukum dan Peradilan, Volume 6 (Nomor 3), 426.

Erwiningsih, Winahyu . (1995). Perlindungan Hukum Tenaga Kerja Wanita. Jurnal Hukum No.3 Vol. 1, 23.

Gusman, Erry. (2019). Perkembangan Teori Konstitusi Untuk Mendukung Negara Kesatuan Republik Indonesia. Ensiklopedia of Journal, Volume 1 (Nomor 2 Edisi 2), 164.

Wahyudi, Slamet Tri. (2012). Problematika Penerapan Pidana Mati. Jurnal Hukum dan Peradilan, Volume 1 (Nomor 2), 217.

Ruslina, Elli. (2012). Makna Pasal 33 Undang-Undang Dasar 1945 Dalam Pembangunan Hukum Ekonomi Indonesia. Jurnal Konstitusi, Volume 9, (Nomor 1), 63.

Mumpuni, Niken Wahyuning Retno. (2021). Satgas Saber Pungli Dalam Penanggulangan Pungutan Liar Di Provinsi Daerah Istimewa Yogyakarta. Jurnal JOM Fisip, Vol 5 (Nomor 1), 114. 